\title{
ANTIHYPERTENSIVE ACTIVITY OF EXTRACT AND FRACTIONS OF MATOA (POMETIA PINNATA J. R \& G FORTS) LEAVES
}

\author{
IKA PURWIDYANINGRUM ${ }^{1,3 *}$, ELIN YULINAH SUKANDAR ${ }^{1}$, IRDA FIDRIANNY ${ }^{2}$
}

${ }^{1}$ Pharmacology-Clinical Pharmacy Research Group, School of Pharmacy, Bandung Institute of Technology, Indonesia. ${ }^{2}$ Pharmaceutical Biology Research Group, School of Pharmacy, Bandung Institute of Technology, Indonesia. ${ }^{3}$ Department of Pharmacology, Faculty of Pharmacy, Setia Budi University, Indonesia. Email: ikafarmasiusb@gmail.com

Received: 18 November 2016, Revised and Accepted: 23 December 2016

\section{ABSTRACT}

Objective: The purpose of this study was to determine antihypertensive activity of extract and fractions of matoa (Pometia pinnata) leaves.

Methods: Matoa leaves were extracted by reflux, followed by evaporating using rotary evaporator. Hypertension was induced by $50 \mathrm{mg} / \mathrm{kg}$ bw. $\mathrm{NaCl}$ and $1.5 \mathrm{mg} / \mathrm{kg}$ bw. prednisone orally, every day as long as 28 days, then continued over the next 28 days in the therapy period. Male Sprague Dawley rats were divided into 12 groups which were hydrochlorothiazide $(0.45 \mathrm{mg} / \mathrm{kg} \mathrm{bw}$.), control group hypertensive, control normal, matoa leaves extract (MLE) (with doses of $50 \mathrm{mg} / \mathrm{kg}$ bw., $100 \mathrm{mg} / \mathrm{kg}$ bw., and $150 \mathrm{mg} / \mathrm{kg} \mathrm{bw}$.), ethylacetate fraction (with doses of $4.35 \mathrm{mg} / \mathrm{kg} \mathrm{bw.,} 8.71 \mathrm{mg} / \mathrm{kg}$ bw., and $13.06 \mathrm{mg} / \mathrm{kg} \mathrm{bw}$.), and water fraction (with doses of $10 \mathrm{mg} / \mathrm{kg}$ bw., $21.88 \mathrm{mg} / \mathrm{kg} \mathrm{bw.,} \mathrm{and} 32.82 \mathrm{mg} / \mathrm{kg} \mathrm{bw}$.). Measurement of systolic and diastolic blood pressure was done every weeks using direct tail-cuff of noninvasive method. Then histomorphology of muscle heart was performed at the end of this research.

Results: Ethylacetate fraction of matoa leaves $13.08 \mathrm{mg} / \mathrm{kg}$ bw. and MLE $150 \mathrm{mg} / \mathrm{kg}$ bw. gave significant result in lowering blood pressure (p<0.05) on the $28^{\text {th }}$ day of therapy and showed an equal profile with hydrochlorothiazide $(0.45 \mathrm{mg} / \mathrm{kg} \mathrm{bw})$. Histomorphological result of rat's muscle heart found collagen production was increased in NaCl-prednisone induced rats.

Conclusions: Extract and fractions of P. pinnata leaves could decrease blood pressure of NaCl-prednisone induced hypertension rats, but this effect was not liniear with doses and they did not decrease the collagen production in cardiac myocardium compared to normal group.

Keywords: Pometia pinnata, Leaves, Hypertension, Tail-cuff noninvasive method, Blood pressure.

(c) 2017 The Authors. Published by Innovare Academic Sciences Pvt Ltd. This is an open access article under the CC BY license (http://creativecommons. org/licenses/by/4. 0/) DOI: http://dx.doi.org/10.22159/ajpcr.2017.v10i3.16221

\section{INTRODUCTION}

Hypertension is one of the cardiovascular problems which can be happened to many people. Hypertension $(6.8 \%)$ is top three, which cause of death after stroke (15.4\%) and tuberculosis (7.5\%). Based on blood pressure measurement was revealed that about $31.7 \%$ of hypertension happened in Indonesian was around 18-year-old. The highest rate of hypertension in Indonesia is in South Kalimantan about $39.6 \%$ of population and West Papua is the lowest rate about $20.1 \%$ of population. Around $7.2 \%$ of health service hypertension was diagnosed and $7.6 \%$ from interview and only $0.4 \%$ of the hypertension patients got medications. Therefore, we know, why health service could only treated $24.0 \%$ out of $31.7 \%$ of hypertension problems. It is around $76.0 \%$ of all hypertension cases has not been treated yet [1]. The World Health Organization also explained that the percentage of hypertension on men (over 25-year-old) is quite larger than women. It is proven that $32.5 \%$ of hypertension happened on men and $29.3 \%$ on women [2].

Cardiovascular disease (CVD) is a group of diseases that affect the heart and blood vessels. Hypertension is one of cardiometabolic risk factors that lead to CVD. Hypertension is increasing in blood pressure, a condition when the blood vessels increase at persistent pressure with systolic blood pressure greater than or equal to $140 \mathrm{mmHg}$ or diastolic blood pressure $\geq 90 \mathrm{mmHg}[2,3]$.

The use of prednisone and $\mathrm{NaCl}$ as an inducer of hypertension has been conducted in several studies. Salt retention is characteristic of human hypertension and can be achieved rapidly in uninephrectomised rats by mineralocorticoid administration, subcutaneous injections as $1 \%$
$\mathrm{NaCl}$ in the drinking water. Corticosterone-induced hypertension, left ventricular (LV) fibrosis, and LV diastolic dysfunction. Prednisone is a compound of mineralocorticoid. Mineralocorticoids cause retention of sodium and water in the body until diuresis occurs due to increase pressure on the kidney. No further retention of sodium and water occurs, but general sodium and water level in the body is slightly increased [4-7].

Physiologically, normal kidney has ability to excrete salt load easily without allowing a marked rise in extracellular volume. However, general epidemiological data have shown that higher average sodium intake in a given population will be greater in the prevalence of hypertension. Chronic ingestion of excess salt will show hypertension in rats, which mimics human hypertension morphologically $[4,8]$.

Nonpharmacological therapy is an important component in treating patients with hypertension. In stage 1 hypertension, blood pressure can be adequately controlled by combination of weight loss (in overweight individuals), restricting sodium intake, increasing aerobic exercise, and moderating consumption of alcohol. It is difficult for many persons to implement. The lifestyle changes can facilitate blood pressure control in patients, but only lifestyle changes insufficient in hypertension patients [9]. It can cause noncompliance in therapy so that a therapeutic target is not reached.

Ethanolic leaves, peels and seed extracts of matoa (Pometia pinnata) which were given by orally could increase urinary excretion. Study regarding relationship between time observation (hours) against the average volume of urine for $4 \mathrm{hrs}$, revealed that all of extracts sample showed diuretic 
effect. Matoa seed extract with dose of $100 \mathrm{mg} / \mathrm{kg} \mathrm{bw}$. showed the highest diuretic effect. The diuretic activity of all of treated extracts (except matoa seed extract with dose $100 \mathrm{mg} / \mathrm{kg} \mathrm{bw}$.) had no significant difference with furosemide. Matoa leaves extract (MLE) with dose of $50 \mathrm{mg} / \mathrm{kg}$ bw. gave the highest sodium levels which were not significantly different compared to furosemide, while the other groups had a significant difference with furosemide $(p<0.05)$. The potassium levels in all of extracts sample had no significant difference with furosemide [10].

Therefore, this is big opportunity to find a new antihypertensive medicine which safe, effective, and high quality. The most natural source to get a good antihypertensive medicine is from plants. There are so many types of plant in Indonesia that have great effect to decrease blood pressure and one of them is matoa (P. pinnata), which has been used by people in Pajang, Surakarta - Central Java, Indonesia.

\section{METHODS}

\section{Materials}

Leaves of matoa (P.pinnata),96\% ethanol,n-hexane,hydrochlorothiazide, prednisone, sodium chloride, sodium carboxymethylcellulose, distilled water, reflux apparatus, rotary evaporator, separatory funnel, and CODA Instrument $t^{\circledR}$.

\section{Preparation of sample}

Leaves of $P$. pinnata were collected from Sukoharjo, Central Java, Indonesia. Sample was determined in Herbarium Bandungense, School of Life Sciences and Technology, Bandung Institute of Technology. Sample was thoroughly washed with tap water, sorted while wet, cut, dried at $50^{\circ} \mathrm{C}$ for 5 days, and grinded into powder.

\section{Extraction}

Sample was extracted by reflux using $96 \%$ ethanol. $500 \mathrm{~g}$ of crude drug was refluxed with $1.5 \mathrm{~L}$ of $96 \%$ ethanol for $3 \mathrm{hrs}$, done triplicate (named as MLE). Liquid extract was filtered and then evaporated using rotary evaporator at $40^{\circ} \mathrm{C}$ and speed of $40 \mathrm{rpm}$.

\section{Fractionation}

Extract was fractionated by liquid-liquid extraction (LLE) with increasing polarity solvent. Ethanol extract $20 \mathrm{~g}$ was added $200 \mathrm{ml}$ of hot water then LLE using n-hexane $200 \mathrm{ml}$. LLE was performed triplicate. Furthermore, the residue was LLE with ethyl acetate $200 \mathrm{ml}$, carried out triplicate, and the residue was water fraction. Hence, there were three kinds of extracts: $\mathrm{N}$-hexane fraction, matoa ethylacetate fraction (MEF), and matoa water fraction (MWF). The obtained fractions were concentrated by rotary evaporator.

\section{Hypertension activity}

This study used 60 male Sprague Dawley rats weighing between 200 and 250 g. Rats were weighed and marked, respectively, and were randomly divided into 12 groups, each group consisted of 5 rats. The groups were MLE with dose of $50 \mathrm{mg} / \mathrm{kg}$ bw. (MLE 1), MLE $100 \mathrm{mg} / \mathrm{kg}$ bw. (MLE 2), MLE $150 \mathrm{mg} / \mathrm{kg}$ bw. (MLE 3), MWF $10 \mathrm{mg} / \mathrm{kg} \mathrm{bw.} \mathrm{(MWF} \mathrm{1),}$ MWF $21.88 \mathrm{mg} / \mathrm{kg}$ bw. (MWF 2), MWF $32.82 \mathrm{mg} / \mathrm{kg}$ bw. (MWF 3), MEF $4.35 \mathrm{mg} / \mathrm{kg}$ bw. (MEF 1), MEF $8.71 \mathrm{mg} / \mathrm{kg} \mathrm{bw}$. (MEF 2), MEF $13.06 \mathrm{mg} / \mathrm{kg}$ bw. (MEF 3), hydrochlorothiazide $4.5 \mathrm{mg} / \mathrm{kg}$ bw., hypertensive control group, and normal group. Previously, rats were fasted for $12 \mathrm{hrs.} \mathrm{Before}$ treatment, the rats were habituation to experimental tool. Habituation is intended that the rats accustomed to a blood pressure tool on direct tail-cuff noninvasive (CODA Instrument ${ }^{\circledR}$ ). Rat was added restrainer for 20 cycles $( \pm 20 \mathrm{~min})$. Then 0 -cuff and VPR-cuff from CODA Instrument ${ }^{\circledR}$ was attached to the base of the tail to test animals accustomed to the pressure of test animals that entered the 0-cuff and VPR-cuff. Habituation was conducted for two weeks [11].

Hypertension was induced by $\mathrm{NaCl} 50 \mathrm{mg} / \mathrm{kg}$ bw. and prednisone $1.5 \mathrm{mg} / \mathrm{kg}$ bw. orally [12] for 28 days and continued for 28 days of therapy. Hydrochlorothiazide (comparator drug), MLE, MWF, and MEF were administered on 28 days, and 28 days later of therapy (totally 56 days). MLE, MWF, MEF, and hydrochlorothiazide were suspended in $1 \%$ CMC-Na, then administered orally to rats.

Observation parameters were systolic and diastolic blood pressure of animals. Measurement was conducted using direct method of noninvasive tail-cuff by CODA Instrument ${ }^{\circledR}$. Measurements were performed before induction ( 0 day [T0]), during induction: Induction of $7^{\text {th }}$ day (T1), induction of $14^{\text {th }}$ day (T2), induction of $21^{\text {st }}$ day (T3), and induction of $28^{\text {th }}$ day (T4) and during therapy: Therapy $7^{\text {th }}$ day (T5), therapy $14^{\text {th }}$ day (T6), therapy $21^{\text {st }}$ day (T7), and therapy $28^{\text {th }}$ day (T8). The results of each group compared to different condition groups and other groups.

\section{Ethics committees}

The permission for conduction of these experiments was obtained from the relevant Ethics Committees, School of Pharmacy - Bandung Institute of Technology.

\section{Statistical analysis}

Data were expressed as mean \pm standard deviation. Statistical analysis was performed using one-way analysis of variance followed by post hoc Tukey. Significant differences were set at values $<0.05$.

\section{RESULTS}

The treatment of animals began with induction of blood pressure for all groups (except the normal control) for 28 days before the therapy and continued for 28 days during therapy. Evaluation of systolic and diastolic blood pressure of animals was measured weekly for 28 days, at T0, T1, T2, T3, and T4. The results can be seen in Tables 1 and 2.

Table 1: The systolic blood pressure of hypertensive-induced rats

\begin{tabular}{llllll}
\hline \multirow{2}{*}{ Group } & \multicolumn{5}{l}{ Systolic blood pressure $(\mathbf{m m H g})$} \\
\cline { 2 - 6 } & T0 & T1 & T2 & T3 & T4 \\
\hline MLE 1 & $105.7 \pm 22.96$ & $131.26 \pm 11.90$ & $136.45 \pm 11.90^{\mathrm{c}}$ & $137.9 \pm 11.88^{\mathrm{c}}$ & $112.3 \pm 8.44^{\mathrm{c}}$ \\
MLE 2 & $108.75 \pm 23.14$ & $128.65 \pm 11.02$ & $136.4 \pm 11.02^{\mathrm{c}}$ & $142.35 \pm 7.86^{\mathrm{c}}$ & $110.5 \pm 16.87^{\mathrm{c}}$ \\
MLE 3 & $111.2 \pm 7.43$ & $132.25 \pm 11.99$ & $134.3 \pm 11.99^{\mathrm{c}}$ & $140.1 \pm 19.02^{\mathrm{c}}$ & $108.15 \pm 14.16^{\mathrm{c}}$ \\
MWF 1 & $107.3 \pm 18.18$ & $127.6 \pm 6.94$ & $135.15 \pm 6.94^{\mathrm{c}}$ & $147 \pm 19.74^{\mathrm{c}}$ & $106.8 \pm 4.08^{\mathrm{c}}$ \\
MWF 2 & $109.5 \pm 8.77$ & $128.85 \pm 9.80$ & $140.3 \pm 9.80^{\mathrm{c}}$ & $143 \pm 5.52^{\mathrm{c}}$ & $109.05 \pm 10.69^{\mathrm{c}}$ \\
MWF 3 & $108.85 \pm 17.56$ & $133.8 \pm 11.23^{\mathrm{c}}$ & $141.7 \pm 11.23^{\mathrm{c}}$ & $148.2 \pm 19.97^{\mathrm{c}}$ & $111.55 \pm 14.05^{\mathrm{c}}$ \\
MEF 1 & $104.1 \pm 5.03$ & $126.75 \pm 7.42$ & $139.3 \pm 7.42^{\mathrm{c}}$ & $144.7 \pm 15.30^{\mathrm{c}}$ & $113.15 \pm 9.76^{\mathrm{c}}$ \\
MEF 2 & $110.35 \pm 12.20$ & $129.65 \pm 4.41$ & $137.7 \pm 4.41^{\mathrm{c}}$ & $143.75 \pm 12.68^{\mathrm{c}}$ & $114.7 \pm 10.64^{\mathrm{c}}$ \\
MEF 3 & $108.9 \pm 6.20$ & $131.8 \pm 5.20$ & $142.1125 \pm 9.81^{\mathrm{c}}$ & $149.95 \pm 20.53^{\mathrm{c}}$ & $117.3 \pm 9.37^{\mathrm{c}}$ \\
HCT & $107.2 \pm 8.93$ & $136.75 \pm 10.94^{\mathrm{c}}$ & $144.675 \pm 17.68^{\mathrm{c}}$ & $145.85 \pm 8.97^{\mathrm{c}}$ & $113.25 \pm 6.94^{\mathrm{c}}$ \\
Hypertension & $108.95 \pm 12.71$ & $130.7 \pm 4.44$ & $138 \pm 2.65^{\mathrm{c}}$ & $143.25 \pm 5.14^{\mathrm{c}}$ & $114.05 \pm 14.03^{\mathrm{c}}$ \\
Control & $106.25 \pm 6.80$ & $106.85 \pm 10.20$ & $104.4 \pm 2.55^{\mathrm{ab}}$ & $105.25 \pm 2.75^{\mathrm{ab}}$ & $78.45 \pm 8.00^{\mathrm{ab}}$ \\
\hline
\end{tabular}

asignificantly different compared to hypertension group $(\mathrm{p}<0.05)$, ${ }^{\mathrm{b}}$ significantly different compared to hydrochlorothiazide ( $\left.\mathrm{p}<0.05\right)$, ${ }^{\mathrm{c}} \mathrm{significantly} \mathrm{different}$ compared to control group ( $\mathrm{p}<0.05)$. MLE: Matoa leaves extract, MWF: Matoa water fraction, MEF: Matoa ethylacetate fraction 
The next treatment was evaluation in lowering of blood pressure of the groups and compared to the control group during 28 days after the induction period. The evaluation was based on parameters of systolic and diastolic blood pressure of rats and measured weekly for 28 days, at $7^{\text {th }}$ day therapy (T5), $14^{\text {th }}$ day therapy (T6), $21^{\text {st }}$ day therapy (T7), and $28^{\text {th }}$ day therapy (T8). The results can be seen in Tables 3 and 4 .

Histomorphology observations of heart muscle of rats can be seen in Figs. 1-4.

\section{DISCUSSION}

Antihypertensive activity test of extract and fractions of matoa leaves were conducted on male Sprague Dawley strain rats. Hypertension was induced using $\mathrm{NaCl} 50 \mathrm{mg} / \mathrm{kg}$ bw. and prednisone of $1.5 \mathrm{mg} / \mathrm{kg}$ bw. orally, every day as long as 28 days. Mineralocorticoids cause retention of sodium and water in the body until diuresis occurs due to increase pressure on the kidneys. No further retention of sodium and water occurs, but general level of body sodium and water is slightly raised [4].

Table 2: The diastolic blood pressure of hypertensive-induced rats

\begin{tabular}{llllll}
\hline \multirow{2}{*}{ Groups } & \multicolumn{5}{l}{ Diastolic blood pressure (mmHg) } \\
\cline { 2 - 6 } & T0 & T1 & T2 & T3 & T4 \\
\hline MLE 1 & $76.2 \pm 5.57$ & $83.575 \pm 10.98$ & $88.45 \pm 16.68$ & $110.65 \pm 3.42^{\mathrm{c}}$ & $112.3 \pm 8.44^{\mathrm{c}}$ \\
MLE 2 & $75.2 \pm 9.88$ & $87.85 \pm 8.82$ & $92.15 \pm 17.53$ & $110.1 \pm 8.09^{\mathrm{c}}$ & $110.5 \pm 16.87^{\mathrm{c}}$ \\
MLE 3 & $74.55 \pm 6.70$ & $90.15 \pm 17.3$ & $103.1 \pm 17.19$ & $107 \pm 12.04^{\mathrm{c}}$ & $108.15 \pm 14.16^{\mathrm{c}}$ \\
MWF 1 & $70.02 \pm 6.72$ & $94.2 \pm 7.43$ & $97.2 \pm 19.16$ & $105.8 \pm 11.33^{\mathrm{c}}$ & $106.8 \pm 4.08^{\mathrm{c}}$ \\
MWF 2 & $74.6 \pm 11.07$ & $84.4 \pm 15.28$ & $101.55 \pm 16.32$ & $109.6 \pm 3.04^{\mathrm{c}}$ & $109.05 \pm 10.69^{\mathrm{c}}$ \\
MWF 3 & $75.4 \pm 22.73$ & $85,8 \pm 14.81$ & $104.15 \pm 15.13$ & $108.75 \pm 2.02^{\mathrm{c}}$ & $111.55 \pm 14.05^{\mathrm{c}}$ \\
MEF 1 & $75.9 \pm 13.97$ & $99.45 \pm 14.70$ & $101.45 \pm 24.21$ & $110.45 \pm 15.70^{\mathrm{c}}$ & $113.15 \pm 9.76^{\mathrm{c}}$ \\
MEF 2 & $72.4 \pm 8.24$ & $87.5 \pm 10.21$ & $111.45 \pm 11.97$ & $112.4 \pm 2.97^{\mathrm{c}}$ & $114.7 \pm 10.64^{\mathrm{c}}$ \\
MEF 3 & $75.35 \pm 9.71$ & $90.85 \pm 6.94$ & $112.28 \pm 17.32$ & $116.45 \pm 12.22^{\mathrm{c}}$ & $117.3 \pm 9.37^{\mathrm{c}}$ \\
HCT & $75.6 \pm 11.03$ & $92.45 \pm 6.36$ & $99.32 \pm 21.12$ & $109.7 \pm 4.19^{\mathrm{c}}$ & $113.25 \pm 6.94^{\mathrm{c}}$ \\
Hypertension & $74 \pm 2.72$ & $89.35 \pm 9.89$ & $106.2 \pm 11.45$ & $111.25 \pm 11.03^{\mathrm{c}}$ & $114.05 \pm 14.03^{\mathrm{c}}$ \\
Control & $76,75 \pm 10.53$ & $81,55 \pm 6.72$ & $79.35 \pm 5.30$ & $82 \pm 4.83^{\mathrm{ab}}$ & $78.45 \pm 8.00^{\mathrm{ab}}$ \\
\hline
\end{tabular}

aSignificantly different compared to hypertension group ( $\mathrm{p}<0.05)$, ${ }^{\mathrm{b}}$ significantly different compared to hydrochlorothiazide ( $\left.\mathrm{p}<0.05\right)$, $\mathrm{c}^{\mathrm{signifi}}$ icantly different compared to control group $(\mathrm{p}<0.05)$. MLE: Matoa leaves extract, MWF: Matoa water fraction, MEF: Matoa ethylacetate fraction

Table 3: The systolic blood pressure during therapy

\begin{tabular}{llllll}
\hline \multirow{2}{*}{ Group } & \multicolumn{5}{l}{ Systolic blood pressure $(\mathbf{m m H g})$} \\
\cline { 2 - 6 } & T4 & T5 & T6 & T7 & T8 \\
\hline MLE 1 & $149.60 \pm 15.94^{\mathrm{c}}$ & $136.8 \pm 9.04$ & $134.15 \pm 9.11$ & $112.95 \pm 19.19^{\mathrm{a}}$ & $109.375 \pm 17.67^{\mathrm{a}}$ \\
MLE 2 & $150.35 \pm 18.52^{\mathrm{c}}$ & $139.6 \pm 11.35^{\mathrm{c}}$ & $130.85 \pm 12.86$ & $128.2 \pm 10.47$ & $113.95 \pm 11.36^{\mathrm{a}}$ \\
MLE 3 & $145.8 \pm 8.24^{\mathrm{c}}$ & $143.15 \pm 13.92^{\mathrm{c}}$ & $138.3 \pm 24.82$ & $129.86 \pm 10.87$ & $103.965 \pm 4.44^{\mathrm{a}}$ \\
MWF 1 & $149.05 \pm 11.40^{\mathrm{c}}$ & $135.05 \pm 8.44^{\mathrm{b}}$ & $135.45 \pm 10.43$ & $131.55 \pm 10.06$ & $126.8 \pm 4.89^{\mathrm{abc}}$ \\
MWF 2 & $148.5 \pm 14.33^{\mathrm{c}}$ & $141 \pm 6.93^{\mathrm{c}}$ & $140.15 \pm 18.81^{\mathrm{c}}$ & $129.65 \pm 22.07$ & $124.75 \pm 3.30^{\mathrm{abc}}$ \\
MWF 3 & $149.47 \pm 9.46^{\mathrm{c}}$ & $142.5 \pm 4.04^{\mathrm{c}}$ & $139.05 \pm 9.19$ & $131.35 \pm 16.22$ & $120.1 \pm 5.95^{\mathrm{a}}$ \\
MEF 1 & $151,4 \pm 9.82^{\mathrm{c}}$ & $132.85 \pm 11.61^{\mathrm{c}}$ & $128.55 \pm 1.32$ & $124.6 \pm 2.67$ & $113.45 \pm 8.40^{\mathrm{a}}$ \\
MEF 2 & $147.73 \pm 8.29^{\mathrm{c}}$ & $130.2 \pm 3.12^{\mathrm{c}}$ & $129.45 \pm 9.12$ & $120.75 \pm 6.72$ & $109.7 \pm 19.76^{\mathrm{a}}$ \\
MEF 3 & $151.1 \pm 7.86^{\mathrm{c}}$ & $143.4 \pm 9.78^{\mathrm{bc}}$ & $129.7 \pm 21.31$ & $119.6 \pm 13.08^{\mathrm{a}}$ & $102.95 \pm 4.47^{\mathrm{a}}$ \\
HCT & $149.15 \pm 9.87^{\mathrm{c}}$ & $120.1 \pm 7.5^{\mathrm{a}}$ & $115.8 \pm 10.61$ & $109.92 \pm 7.90^{\mathrm{a}}$ & $101.25 \pm 4.06^{\mathrm{a}}$ \\
Hypertension & $148.6 \pm 7.51^{\mathrm{c}}$ & $148 \pm 10.70^{\mathrm{bc}}$ & $149.17 \pm 16.69^{\mathrm{c}}$ & $151.1 \pm 13.98^{\mathrm{bc}}$ & $155 \pm 2.44^{\mathrm{bc}}$ \\
Control & $103.7 \pm 5.92^{\mathrm{ab}}$ & $104.6 \pm 6.08$ & $105 \pm 4.32^{\mathrm{a}}$ & $103.4 \pm 4.55^{\mathrm{a}}$ & $101.1 \pm 3.03^{\mathrm{a}}$ \\
\hline
\end{tabular}

aSignificantly different compared to hypertension group ( $\mathrm{p}<0.05)$, ${ }^{\mathrm{b}}$ significantly different compared to hydrochlorothiazide ( $<<0.05$ ), ${ }^{\mathrm{c}}$ significantly different compared to control group $(\mathrm{p}<0.05)$. MLE: Matoa leaves extract, MWF: Matoa water fraction, MEF: Matoa ethylacetate fraction

Table 4: The diastolic blood pressure during therapy

\begin{tabular}{llllll}
\hline \multirow{2}{*}{ Group } & \multicolumn{5}{l}{ Diastolic blood pressure (mmHg) } \\
\cline { 2 - 6 } & T4 & T5 & T6 & T7 & T8 \\
\hline MLE 1 & $112.3 \pm 8.44^{\mathrm{c}}$ & $112.25 \pm 23.9^{\mathrm{c}}$ & $94.6 \pm 10.1$ & $91.55 \pm 15.70$ & $85.53 \pm 4.92$ \\
MLE 2 & $110.5 \pm 16.87^{\mathrm{c}}$ & $110.1 \pm 8.23^{\mathrm{c}}$ & $101.1 \pm 5.75$ & $95.25 \pm 13.63$ & $84.55 \pm 2.74^{\mathrm{a}}$ \\
MLE 3 & $108.15 \pm 14.16^{\mathrm{c}}$ & $107.55 \pm 3.25^{\mathrm{c}}$ & $98.35 \pm 23.71$ & $93.2 \pm 11.88$ & $82.26 \pm 3.4^{\mathrm{a}}$ \\
MWF 1 & $106.8 \pm 4.08^{\mathrm{c}}$ & $105 \pm 3.66^{\mathrm{c}}$ & $100.55 \pm 20.70$ & $98.8 \pm 13.93$ & $97.25 \pm 7.66$ \\
MWF 2 & $109.05 \pm 10.69^{\mathrm{c}}$ & $103.6 \pm 13.99^{\mathrm{c}}$ & $104.35 \pm 8.73^{\mathrm{c}}$ & $100.05 \pm 23.44$ & $94 \pm 6.68$ \\
MWF 3 & $111.55 \pm 14.05^{\mathrm{c}}$ & $109.5 \pm 7.97^{\mathrm{c}}$ & $109.55 \pm 7.75^{\mathrm{c}}$ & $105.6 \pm 18.05$ & $102.2 \pm 22.59$ \\
MEF 1 & $113.15 \pm 9.76^{\mathrm{c}}$ & $110.85 \pm 8.81^{\mathrm{c}}$ & $93.8 \pm 20.87$ & $97.1 \pm 12.56$ & $92.35 \pm 17.67$ \\
MEF 2 & $114.7 \pm 10.64^{\mathrm{c}}$ & $113.5 \pm 3.10^{\mathrm{c}}$ & $86.5 \pm 1.11$ & $86.45 \pm 6.86$ & $83.65 \pm 26.70^{\mathrm{a}}$ \\
MEF 3 & $117.3 \pm 9.37^{\mathrm{c}}$ & $114.55 \pm 15.85^{\mathrm{c}}$ & $100.4 \pm 7.28$ & $91.9 \pm 9.25$ & $82.6 \pm 4.94^{\mathrm{a}}$ \\
HCT & $113.25 \pm 6.94^{\mathrm{c}}$ & $99.45 \pm 11.36$ & $87.9 \pm 6.27^{\mathrm{c}}$ & $84.35 \pm 13.30$ & $83.35 \pm 15.87^{\mathrm{a}}$ \\
Hipertension & $114.05 \pm 14.03^{\mathrm{c}}$ & $114.5 \pm 5.19^{\mathrm{c}}$ & $115.66 \pm 6.23^{\mathrm{c}}$ & $115.95 \pm 4.22^{\mathrm{bc}}$ & $116.75 \pm 0.95^{\mathrm{bc}}$ \\
Control & $78.45 \pm 8.00^{\mathrm{ab}}$ & $72.2 \pm 8.05^{\mathrm{a}}$ & $74.75 \pm 13.59^{\mathrm{a}}$ & $76.5 \pm 11.67^{\mathrm{a}}$ & $74.2 \pm 5.71^{\mathrm{a}}$ \\
\hline
\end{tabular}

${ }^{a}$ Significantly different compared to hypertension group ( $\left.\mathrm{p}<0.05\right)$, ${ }^{\mathrm{b}}$ significantly different compared to hydrochlorothiazide ( $\left.\mathrm{p}<0.05\right)$, ${ }^{\mathrm{c}}$ significantly different compared to control group $(\mathrm{p}<0.05)$. MLE: Matoa leaves extract, MWF: Matoa water fraction, MEF: Matoa ethylacetate fraction 


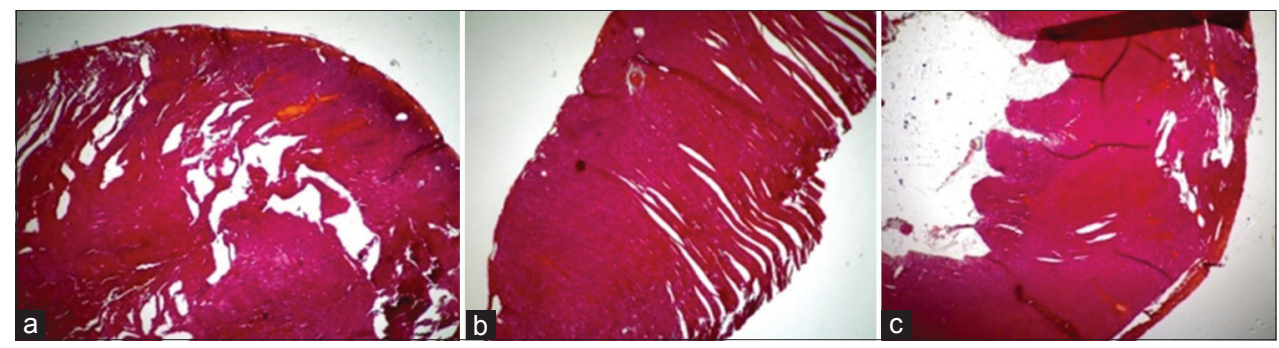

Fig. 1: The cross-section of heart muscle histology on $\times 40$ magnification, the collagen green transparent with Masson's trichrome staining. (a) Control, (b) hypertension, (c) matoa water fraction 2

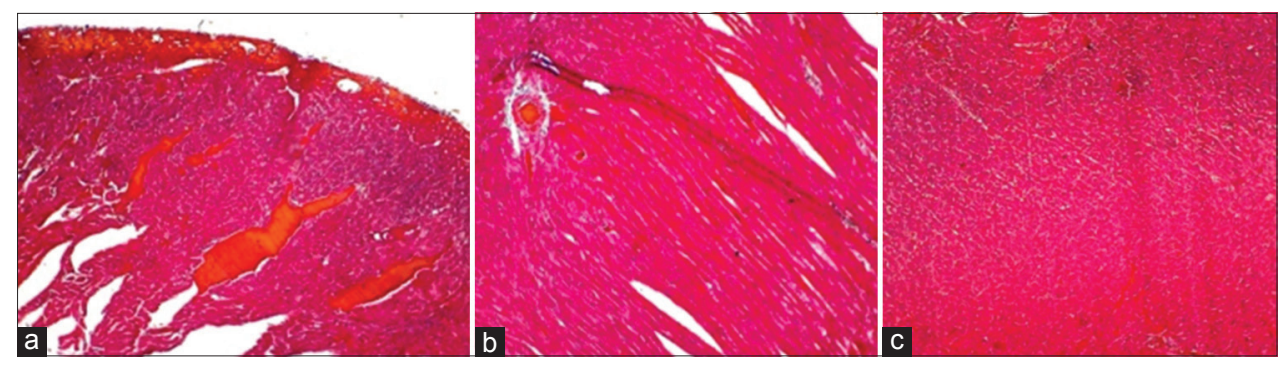

Fig. 2: The cross-section of heart muscle histology on $\times 100$ magnification, the collagen green transparent with Masson's trichrome staining. (a) Control, (b) hypertension, (c) matoa water fraction 2

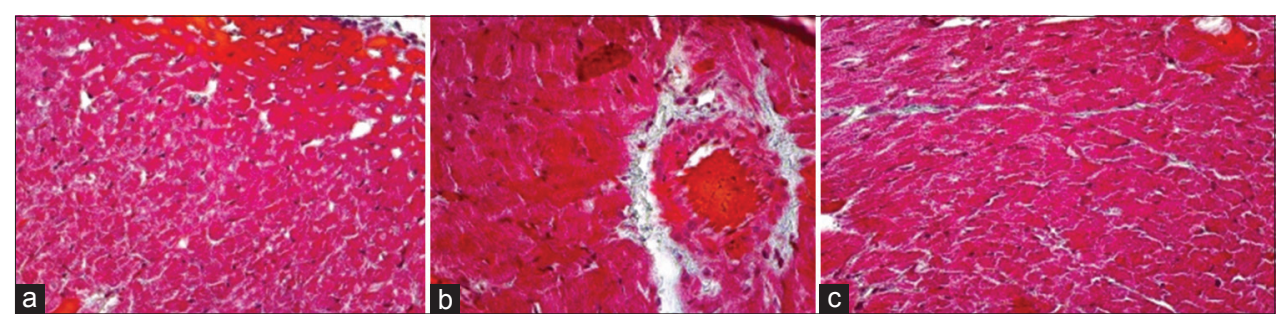

Fig. 3: The cross-section of heart muscle histology on $\times 400$ magnification, the collagen green transparent with Masson's trichrome staining. (a) Control, (b) hypertension, (c) matoa water fraction 2
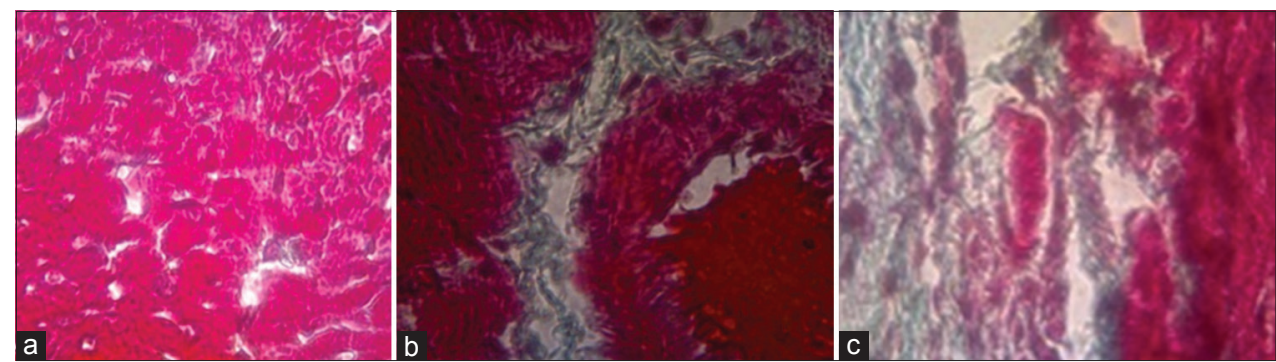

Fig. 4: The cross-section of heart muscle histology on $\times 1000$ magnification, the collagen green transparent with Masson's trichrome staining. (a) Control, (b) hypertension, (c) matoa water fraction 2

Male Sprague Dawley rats were divided into 12 groups which were hydrochlorothiazide $(0.45 \mathrm{mg} / \mathrm{kg}$ bw.), control hypertensive, control normal, MLE (with doses of $50 \mathrm{mg} / \mathrm{kg}$ bw., $100 \mathrm{mg} / \mathrm{kg}$ bw., $150 \mathrm{mg} / \mathrm{kg}$ bw.), ethylacetate fraction (with doses of $4.35 \mathrm{mg} / \mathrm{kg}$ bw., $8.71 \mathrm{mg} / \mathrm{kg}$ bw., $13.06 \mathrm{mg} / \mathrm{kg}$ bw.), and water fraction (with dose of $10 \mathrm{mg} / \mathrm{kg}$ bw., $21.88 \mathrm{mg} / \mathrm{kg}$ bw., $32.82 \mathrm{mg} / \mathrm{kg}$ bw.).

In pharmacological experiments to determine the pharmacological activity using animal model, there are several steps that must be met. Before animal treatment in this study, acclimatization to the laboratory conditions and habituation with blood pressure tool on tail-cuff noninvasive CODA Instrument ${ }^{\circledR}$ were conducted for 2 weeks. It was done so that the animals get habitual with the laboratory conditions and tools that do not affect the measurement data. The average of normal systolic blood pressure at 0 day (T0) was $108.09 \pm 2.03 \mathrm{mmHg}$ $(\mathrm{p}=1.00)$ and diastolic blood pressure was $74.66 \pm 1.84 \mathrm{mmHg}$ ( $p=1.00$ ) with $95 \%$ degree of confidence, then analysis was continued by parametric test.

The increasing in blood pressure induction of all groups was compared to control group. This phase aimed to test the ability of $\mathrm{NaCl}$ and prednisone to increase blood pressure, by analyzing systolic and diastolic blood pressure every week, started at 0 day (T0) until $28^{\text {th }}$ day (T4) induction period, showed that there were no significant difference between systolic and diastolic blood pressure of all groups which were induced by $\mathrm{NaCl}$ and prednisone on day 28 of induction (T4) (Tables 1 and 2). Based on the obtained results, it can be concluded that induction by $\mathrm{NaCl}$ and prednisone for 28 days, increased the systolic and diastolic blood pressure on male Sprague Dawley strain rats significantly compared to the control group $(\mathrm{p}<0.05)$. 
The next evaluation was to measure blood pressure during therapy. The results in lowering blood pressure during therapy treatment were compared to hypertension group and control group. The aim of this phase was to test the ability of sample in delivering antihypertensive effect. Comparison between hydrochlorothiazide $0.45 \mathrm{mg} / \mathrm{kg}$ bw. and control group was aimed to validate the testing method in decreasing in blood pressure of test animals. Based on the analysis of systolic and diastolic blood pressure every week, started at $0^{\text {th }}$ day (T4) until $28^{\text {th }}$ day duration of therapy (T8), demonstrated that there were significant difference between systolic (at T5 until T8) and diastolic (beginning at the $28^{\text {th }}$ day of therapy T8) of hydrochlorothiazide group compared to hypertension group $(\mathrm{p}<0.05)$.

In addition, comparison between hydrochlorothiazide to control group was also to see the effectiveness of hydrochlorothiazide in lowering in blood pressure to reach normal. There were no significant difference in systolic blood pressure (started at T5) and diastolic (started at T5) between hydrochlorothiazide to control group. It can be concluded that hydrochlorothiazide was effective to decrease blood pressure closed to normal, started at T5 (at $7^{\text {th }}$ day therapy).

The comparison between hypertension group and control group was carried out by analyzing the systolic and diastolic blood pressure every week started at $0^{\text {th }}$ day (T4) until $28^{\text {th }}$ day (T8) during the therapy. There was significantly different in systolic and diastolic blood pressure of hypertension group and control group during the treatment period $(\mathrm{p}<0.05)$. It can be concluded that $\mathrm{NaCl} 50 \mathrm{mg} / \mathrm{kg}$ bw. and prednisone $1.5 \mathrm{mg} / \mathrm{kg}$ bw. which were administered orally and then continued for 28 days of therapy was able to keep significantly different blood pressure compared to hypertension group $(\mathrm{p}<0.05)$.

The next step was to compare sample groups (MLE 1, MLE 2, MLE 3, MWF 1, MWF 2, MWF 3, MEF 1, MEF 2, and MEF 3) and hypertension group, to test the ability antihypertensive effect of sample groups. Based on the analysis of systolic blood pressure weekly during the treatment (T5 until T8), it can be seen there were significant difference between MLE 1, MLE 2, MLE 3, MWF1, MWF 2, MWF 3, MEF 1, MEF 2, and MEF 3 compared to hypertension group at T8 $(\mathrm{p}<0.05)$, while the MLE 1 and MEF 3 groups started at T7 (Table 3). Diastolic blood pressure started giving significantly decrease at T8 (28 ${ }^{\text {th }}$ day of therapy) in MLE 2, MLE 3, MEF 2, and MEF 3 compared to hypertension group $(\mathrm{p}<0.05)$. It can be concluded that the MEF 2 gave significantly decrease $(\mathrm{p}<0.05)$ compared to hypertension group started from $21^{\text {th }}$ day until the end of therapy, while MLE 2, MLE 3 and MEF 3 started from $28^{\text {st }}$ day.

The sample was also compared to control group to test the ability of sample to provide antihypertensive effect to normal blood pressure. Based on statistical analysis every week started at $0^{\text {th }}$ day (T4) until $28^{\text {th }}$ day (T8) therapy, the results denoted that systolic blood pressure of all sample groups was not significantly different with the control group started at $14^{\text {th }}$ day (T6) to $28^{\text {th }}$ day (T8) therapy (except systolic of MWF 2 at T6), while diastolic blood pressure of all sample groups gave no significant difference with control started at $14^{\text {st }}$ day (T6) (except MWF 2 and MWF 3 until $28^{\text {th }}$ day (T8).

Furthermore, the comparison between sample group and hydrochlorothiazide group to prove the effectiveness of antihypertensive effect of sample. It can be seen in Tables 3 and 4, there was no significant difference between sample groups and hydrochlorothiazide group (except systolic of MWF 1 at T5 and MEF 1 and MEF 2 at T8).

Research by Joshi resulted that extract of Evolvulus alsinoides herb in adrenaline-induced hypertensive rats was significantly decreased compared to control hypertensive group [13]. Previous study by Alamgeer et al. [14] exposed that aqueous methanol extract of Caralluma tuberculata possessed antihypertensive activity in rats which was hypertension with egg-fed and glucose induced.
Research by Jena resulted that a rise in blood pressure was found on day $16^{\text {th }}$ on fructose-induced hypertension rats. Ethanolic extract of Eclipta alba decreased the rise in blood pressure significantly in a dosedependent manner comparable to quinapril [15].

Based on the results of histological observation, there was increasing in spread of collagen in heart muscle of hypertensive rat which induced by $\mathrm{NaCl}$-prednisone. The heart muscle in hypertensive rats was damage compared to control group which its muscle fiber was still good. This damage can indicate myocardial fibrosis. Mohanty et al. [16] stated that the chronic administration of prednisone could increase the risk of cardiac perivascular fibrosis. Myocardium on hydrochlorothiazide group was better than the hypertension group. In contrast with calcium channel blocker agent, the antihypertensive effect of diuretic such as hydrochlorothiazide may be due to chronic sodium depletion which resulted decreasing in responsiveness of the efferent sympathetic nervous system or modification of the affinity of arterial smooth muscle receptors for angiotensin and norepinephrine [16].

Angiotensin receptor blocker will inhibit the synthesis of collagen type 1 in patients with hypertension [17]. Therefore, the thiazides will inhibit stimulation of fibroblasts to produce collagen. On the other hand, the extract and fractions of matoa ( $P$. pinnata) leaves were not able to repair damage the heart muscle caused by hypertension.

The previous study demonstrated analysis of collagen levels using image analyzer. The Image software did not show a significant difference between the test groups compared to positive and negative ones. Based on these images, it could be seen that the collagen network which was formed in positive control group and the test group (captopril, losartan, and amlodipine) higher than the negative control group. Increasing in blood pressure could increase synthesis of collagen in heart and also cardiac collagen [18].

\section{CONCLUSION}

Extract and fractions of P. pinnata leaves could decrease blood pressure of $\mathrm{NaCl}$-prednisone induced hypertension rat. The effect was not liniear with dosage and they did not decrease the collagen production in cardiac myocardium.

\section{ACKNOWLEDGMENT}

Thanks to Setia Budi Foundations on scholarships awarded so as to fund this research.

\section{REFERENCES}

1. Department of Health RI. Reports Results of Health Research in Indonesia on 2007. Jakarta: Research and Development of Health Centers-Department of Health RI; 2008.

2. World Health Organization. A Global Brief on Hypertension. Geneva: WHO Press; 2013.

3. National Heart, Lung and Blood Institute. The Seventh Report of the Joint National Committee on Prevention, Detection, Evaluation and Treatment of High Blood Preasure (JNC 7). Bethesda: NIH Publication; 2003. p. 1-34

4. Badyal DK, Lata H, Dadhich AP. Animal models of hypertension and effect of drugs. Indian J Pharmacol 2003;35:349-62.

5. Hattori T, Murase T, Iwase E, Takahashi K, Ohtake M, Tsuboi K, et al. Glucocorticoid-induced hypertension and cardiac injury: Effects of mineralocorticoid and glucocorticoid receptor antagonism. Nagoya $\mathrm{J}$ Med Sci 2013;75(1-2):81-92.

6. Sinha A, Bagga A. Pulse steroid therapy. Indian J Pediatr 2008;75:1057-66.

7. Doggrell SA, Brown L. Rat models of hypertension, cardiac hypertrophy and failure. Cardiovasc Res 1998;39(1):89-105

8. Dahl LK. Possible role of salt intake in the development of essential hypertension. In: Pork KD, Cottier PT, editors. Essential HypertensionAn International Symposium. Berlin: Springer-Verlag; 1960. p. 53-65.

9. Brunton LL, Lazo JS, Parker KL. Godman and Gilman's the Pharmacological Basis of Therapeutics. $11^{\text {th }}$ ed. USA: The McGrawHill Companies; 2006. 
10. Purwidyaningrum I, Sukandar EY, Fidrianny I. Diuretic activity of different organs of matoa (Pometia pinnata) extracts and its influence on potassium and sodium level. Int J Pharm Phytochem Res 2016;8(2):244-7.

11. Vogel G. Drug Discovery and Evaluation Pharmacological Assays. USA: Springer; 1997.

12. Yuliandra, Armenia A, Arifin H. Study of antihypertensive effects of plant rope princess (Cassytha filiformis L.) in rats induced hypertension prednisone and salt. Proceedings of the National Seminar on Recent Developments III Clinical Pharmacy and Science in 2013

13. Joshi UH, Ganatra TH, Desai TR, Tirgar PR. Evaluation of antihypertensive activity of evolvulus alsinoides in adrenaline induced hypertensive rats. Int J Pharm Pharm Sci 2012;4(4):194-8.

14. Alamgeer T, Malik M, Mushtaq M, Khan J, Qayyum R, Khan AQ, et al. Evaluation of antihypertensive effect of aqueous methanol extract of
Caralluma tuberculata N.E.Br in Sprauge Dawley rats. Trop J Pharm Res 2015;14(3):455-62.

15. Jena M, Jena J, Biswal SB, Mishra S, Pal A. Effect of Eclipta alba on fructose induced hypertension in albino rats. Int $\mathrm{J}$ Pharm Pharm Sci 2013;5(3):281-5

16. Mohanty PK, Sowers JR, Thames MD. Effects of hydrochlorothiazide and diltiazem on reflex vasoconstriction in hypertension. Hyper AHA J 1989;10(35):35-42.

17. Lopez B, Gonzalez A, Varo N, Laviades C, Querejeta R, Diez J. Biochemical assessment of myocardial fibrosis in hypertensive heart disease. Hyper AHA J 2001;38(5):1222-5.

18. Suliska N, Sukandar EY. The effectivity of captopril, losartan and amlodipine on hypertension in rat model of gentamicin-induced renal failure. Int J Pharm Pharm Sci 20146(6):146-51. 